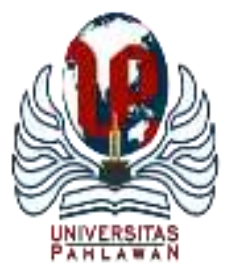

Edukatif : Jurnal Ilmu Pendidikan Volume 3 Nomor 4 Tahun 2021 Halm 2411 - 2417

EDUKATIF: JURNAL ILMU PENDIDIKAN

Research \& Learning in Education

https://edukatif.org/index.php/edukatif/index

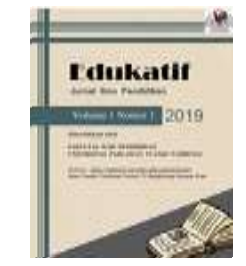

\title{
Strengthening Pancasila Values During the Covid-19 Pandemic
}

\author{
Jagad Aditya Dewantara ${ }^{1 凶}$, T Heru Nurgiansah $^{2}$ \\ Universitas Tanjungpura ${ }^{1}$ \\ Universitas PGRI Yogyakarta ${ }^{2}$ \\ E-mail : $\underline{\text { Jagad02@ fkip.untan.ac.id }}{ }^{1}, \underline{\text { nurgiansah@upy.ac.id }}^{2}$
}

\begin{abstract}
Abstrak
Pancasila merupakan pedoman bagi bangsa Indonesia dalam menjalankan kehidupan sehari-hari. Sejak 2020 Indonesia berada di masa Pandemi Covid-19. Tujuan dari penelitian ini adalah utuk mengetahui dan menganalisis penguatan nilai-nilai Pancasila di masa Pandemi Covid-19. Metode yang digunakan adalah pendekatan deskriptif kualitatif dengan teknik pengumpulan data melalui observasi, wawancara, dokumentasi, dan literasi. Hasil dari penelitian menunjukan bahwa nilai-nilai Pancasila harus semakin dikuatkan dalam menghadapi Pandemi Covid-19 di Indonesia. Penguatan nilai Pancasila ini tercermin dalam penerapan protokol kesehatan yakni, rajin mencuci tangan, senantiasa memakai masker, menjaga jarak, menghindari keramaian dan menahan diri dari mobilitas masa. Jika penerapan protokol kesehatan tersebut dilaksanakan dengan baik maka hal tersebut sejalan dengan nilai-nilai yang terkandung dalam pancasila.
\end{abstract}

Kata kunci: Pancasila, Pandemi Covid-19.

\begin{abstract}
Pancasila is a guideline for Indonesians in carrying out their daily lives. Since 2020 Indonesia is in the covid19 pandemic. The purpose of this study is to know and analyze the strengthening of Pancasila values during the Covid-19 pandemic. The method used is a qualitative descriptive approach with data collection techniques through observation, interview, documentation, and literacy. The results of the research showed that the values of Pancasila should be strengthened in the face of the Covid-19 Pandemic in Indonesia. The strengthening of Pancasila value is reflected in the application of health protocols, namely, diligently washing hands, always wearing masks, maintaining distance, avoiding crowds, and refraining from the mobility of time. If the implementation of the health protocol is implemented properly then it is in line with the values contained in pancasila.
\end{abstract}

Keywords: Pancasila, Pandemic Covid-19.

Copyright (c) 2021 Jagad Aditya Dewantara, T Heru Nurgiansah

$\triangle$ Corresponding author

Email : Jagad02@fkip.untan.ac.id

DOI : https://doi.org/10.31004/edukatif.v3i4.443

ISSN 2656-8063 (Media Cetak)

ISSN 2656-8071 (Media Online) 


\section{Strengthening Pancasila Values During the Covid-19 Pandemic - Jagad Aditya Dewantara, T Heru Nurgiansah}

DOI: https://doi.org/10.31004/edukatif.v3i4.443

\section{INTRODUCTION}

Pancasila has a position as the basis of philosophy as well as the basis of the state and the view of the life of the Indonesian nation. Pancasila which is domiciled as the basis of the state, the view and philosophy of life should be prayed by the Indonesian nation in the process of organizing the life of society, nation, and state in realizing the ideals of the proclamation of independence (Siahaan, 2020). The values contained in it are noble values that are excavated by the nation's culture and have a universally recognized basic value and will not be changed by the passage of time. Because the value contained in Pancasila is the cultural value of the nation, it should be preserved (Asmaroini, 2016).

To preserve these values, action or implementation of each individual in their daily lives is required. In implementing the values of Pancasila, of course, there are always obstacles and challenges. In the past, the implementation of Pancasila values was felt not optimally by every citizen. This is because the number of foreign cultures that change into Indonesia is widespread (Kahin, 2013). The flow of globalization is not only spreading positive things but also negative things. This is evidenced by the number of teenagers who love or admire the culture of other nations that are not following the values of Pancasila. In addition to the challenges of globalization, there is a new challenge that comes to the Indonesian nation, namely the Covid-19 pandemic.

This pandemic is caused by the Covid-19 coronavirus that originally originated in China. This virus is increasingly widespread throughout the world, including in Indonesia (Dewantara \& Nurgiansah, 2021b). Even right in one year of Covid-19, the number of positives affected by this virus reached 1.5 million in Indonesia. Coronavirus there are several variants, there are about 4 new variants of coronavirus. The first was the B.1.1.7 variant which was first confirmed in the UK.

The existence of B.1.1.7 variants entering Indonesia also makes people worried. Especially since this virus is called more contagious. Second, there is B.1.351 or 501Y V2 which originated in South Africa. According to the World Health Organization (WHO), this variant has already spread to more than 30 other countries. The third is the P.1 variant from Brazil, first detected in mid-January, on travelers from the Brazilian state of Amazonas who go to Japan. another new variant of coronavirus is CAL.20C, which currently accounts for half of the COVID-19 cases in Southern California (Dewantara \& Nurgiansah, 2021a).

The many new variants of Covid-19 make a concern for all circles of society. Even new variants of Covid-19 have entered Indonesia, this makes Indonesians increasingly panicked about this virus. Besides, the pandemic that is felt to have not receded continues to have an impact on the lives of all circles. In the middle of that, people are required to be able to adapt to new habits in this Pandemic era. Changes in habits during pandemics like this are certainly experienced by all people in the world or Indonesia in particular. New policies to address this pandemic problem have been well prepared by the ranks of the political elite. Not infrequently many parties have not adapted well.

The novelty in this article is the strengthening of pancasila values is getting better in the midst of the outbreak. Before the pandemic, pancasila values were applied without applying health protocols. This research is very important because to know the application and strengthening the value of pancasila in the midst of the covid-19 pandemic.

\section{RESEARCH METHODS}

This type of research used is a qualitative descriptive approach. The use of this approach aims to describe the behavior or attitude of the community in applying the values of Pancasila during the Covid-19 pandemic. for the research location is in Kampung Cikopo RW 07 Bumiwangi Village, Ciparay District, Bandung Regency, West Java. Data acquisition instruments are obtained from the process of direct 


\section{Strengthening Pancasila Values During the Covid-19 Pandemic - Jagad Aditya Dewantara, T Heru Nurgiansah}

DOI: https://doi.org/10.31004/edukatif.v3i4.443

observation in the field, interviews with several citizens, and journal studies or news relevant to the discussion.

The steps in this study are (1) Preliminary Study, by looking at the phenomena that exist in Indonesian society in general and Bumiwangi villagers especially, (2) to get accurate information, the author begins to make direct observations in the field, conduct interviews in a non-formal manner to several communities and added from journal studies or news relevant to the discussion, (3) interpretation, after the data is collected then the author interprets the results of the data and draws conclusions.

\section{RESULTS OF RESEARCH AND DISCUSSION}

The description of each Sila Pancasila is as follows: The efforts to apply each of the principles of Pancasila are as follows:

\section{Please The One True God}

This value of the Godhead relates to an individual's association with something considered sacred, sacred, glorious, and noble. Understanding godliness as a view of life is to realize a full society, namely building an Indonesian society that has the soul and spirit to achieve God's pleasure in every good deed it does (Dewantara et al., 2021).

During the Covid-19 pandemic, people are encouraged to perform worship in their own homes. But now after the application of new normality, the mosque has been visited again by its worshippers. In Kampung Cikopo RW 07, Friday prayers have been conducted again in the mosque with the condition of using masks following health protocols from the government. Madrasah for children to recite about religion can also be re-implemented with the record of children using masks or face shields. Limitations when worshipping in this pandemic are seen as there is wisdom and teaching. That, the relationship with God will not always be linear by doing worship activities in mosques, churches, temples, or other places of worship. All it takes is to be able to create special relationships and communication, and worship is not just a manipulative relationship that comes to God when it comes to the village (Anwar \& Salim, 2019).

The value of God governs man's relationship with the creator (Nurgiansah et al., 2020). This includes the ordinances of worship about religious religions and their respective beliefs. The value of godliness will be in line with the value of community expectations. With the Covid-19 pandemic, people are getting closer to the makers so that the health and strength of the pandemic.

\section{Please a Just and Civilized Humanity}

The value of this country of humanity means that the state must uphold the dignity and dignity of human beings. In this second syllabus, the verse also values awareness, awareness of moral attitudes, and human behavior which must become norms and cultures either above oneself, fellow human beings, or in the environment (Kurniawan, 2015).

The value of humanity means to humanize human beings according to their dignity, degrees, and dignity as human beings. Treating people humanely in various societies, nationalities, and states. Humanity has always been based on human rights that are inherent in human beings since human beings were born that are universal in nature. Universal means to apply anywhere, under any circumstances and circumstances. Indonesia has its own rules on human rights stipulated in Law No. 39 of 1999 (Nurgiansah, 2020b).

In the value of humanity, all communities have the right to get fair protection and assistance from the government. Therefore, citizens get one consequence of that is to carry out the obligation to comply with the laws and policies issued by the Government during this pandemic (Januar Mahardhani, 2020). The results of the Central Statistics Agency (BPS) survey on the social condition of demographics impact of COVID-19 


\section{Strengthening Pancasila Values During the Covid-19 Pandemic - Jagad Aditya Dewantara, T Heru Nurgiansah}

DOI: https://doi.org/10.31004/edukatif.v3i4.443

shows that the recommendations for physical distancing are understood in detail by $87 \%$ of respondents, and implemented by $72 \%$ of the public. However, awareness to comply with government policy has not been fully seen in the residents of RW 07 Kampung Cikopo. Sometimes some people still do not realize that wearing a mask when out of the house is important. This is shown when residents go to the spilled market which meets many people, some residents still do not wear masks and keep their distance.

\section{Please The Association of Indonesia}

The value of Indonesian unity means that the state is the incarnation of the nature and nature of human monodualis which means human beings as individual beings and social beings. A state is an alliance of living together among the constituent elements of a state in the form of tribes, groups, races, groups, or religious groups. Therefore, the difference is the human nature and characteristics of the elements that make up the country. Differences are not intended to be a conflict and hostility but rather should be directed at a mutually beneficial synthesis (Nurgiansah, 2021b).

In this pandemic, a sense of nationalism, kinship, and cooperation is needed once (Nurgiansah, 2020a). People can stand shoulder to shoulder in the face of pandemics by providing material or non-material assistance as well as prayers to our brothers and sisters. This is very noticeable in Rw 07 community, especially when there is Friday Prayer at Nurul Hidayah Mosque. After performing the prayer, the pilgrims are usually given rice boxes by the benefactors regardless of which group or social status. United in compliance with the provisions of the law to deal with the Covid pandemic, empathy must be able to give birth to mutual unity to solve the problem (Nafisah, 2016). Helping each other, sharing, and collaborating regardless of race, ethnicity, and religion is the meaning of the third precept.

In addition to providing material assistance, increasing mutual assistance during the pandemic is to always adhere to what has been determined by the government. This is in line with Kurnia's thinking, that every Indonesian citizen is obliged to carry out the regulations that have been made by the government. Because the rules are made for the benefit of the common good (Krisnawati et al., 2020).

\section{Populist Sila Led by Wisdom of Wisdom in Representative Deliberation}

Human beings as social beings certainly need to coexist with others. In interactions with others, there is usually an agreement, mutual respect with common goals and interests (Novitasari et al., 2019). It is also in line with the meaning of populist values in Pancasila. Populist values contain the meaning of a government that is from the people, by the people, and for the people conducted by consensus deliberations through representative institutions of the people (Nurgiansah, 2021a).

The value of this fourth principle means that the decisions or policies taken are the results of deliberations as well as joint decisions that are then implemented together for the safety and interests of the nation itself. The application of this value during the pandemic is how community leaders can coordinate to understand the community about the importance of carrying out advice from the government so as not to conduct activities outside the home (Cahyono et al., 2018).

Such an application is strongly felt in the Rw 07 area of Cikopo Village, seen when there are activities that would otherwise gather a lot of people. Public figures always urge to use a mask and do not forget to wash their hands first or use a hand sanitizer. On Eid al-Adha $1441 \mathrm{H}$, the citizens who participated in the slaughter of Qurban animals were always reminded by the Chairman of RT as the leader among him to always use masks even to be provided masks from the committee.

\section{Please Social Justice for All Indonesians}

In the fifth syllabus, social justice for all people has the means that there is personal and social justice. Personal justice is individual or individual justice and social justice is justice together. All Indonesians get the 


\section{Strengthening Pancasila Values During the Covid-19 Pandemic - Jagad Aditya Dewantara, T Heru Nurgiansah}

DOI: https://doi.org/10.31004/edukatif.v3i4.443

right to justice in law, economy, politics, and socio-culture without any impartiality in a particular group or person (Octavia \& Rube'i, 2017).

Social justice for all Indonesians means that the country must do its society fairly. In times of pandemics like this, the fairness of people's handling should not be done differently. In this adaptation period of new habits, not only groups of rich people who live, do not starve and get health facilities, small people should also get the same opportunity. That is, that every element of society is entitled to the feasibility of living in this pandemic not only for the rich (Hastangka \& Farid, 2020).

In times of pandemics like this, people in the lower middle class get a lot of direct assistance from the government which will help the economic burden of their families. This assistance is provided in the form of basic food aid and there is direct assistance in cash. Also, the government launched a pre-work card program with a budget of up to 20 Trillion Rupiah. This program is not specific to the victims of layoffs but to all unemployed including those who have just completed formal education (Bunyamin, 2008).

The assistance was felt by the residents of RW 07 Kampung Cikopo. One of the important targets in the elderly. As experienced by Grandma Inch, she got rice assistance provided by the village. Besides, many unemployed people also apply for the Pre-Employment Card program, so they get cash assistance. In addition to Prakerja, there is assistance from BPJS Ketenagakerjaan provided to factory employees. Assistance either in the form of BLT or voluntary assistance from a group of people is very helpful. Assistance from the government can help people's lives in their survival. This is because, during the Covid-19 pandemic, many people lost their jobs which had a direct impact on their lives. This assistance can make the poor less poor and have nothing.

In addition to the residents who actively register for assistance. The role of the Chairman of RT or other public figures must be very active. For example, rt 04 and 03 can coordinate with each other in distributing aid. When RT 03 gets more after divided, it will be distributed to citizens of RT 04 who are still deficient. This is also very following the value of justice for all Indonesians without discriminating.

The Covid-19 pandemic provides a great opportunity for all elements of society to be able to realize social justice for all. The government is currently rolling out various cards to help low-income people so they can still survive during this pandemic (Nurgiansah \& Sukmawati, 2020).

The limitation in this study is the application of health protocols so that research can not be done freely as under normal circumstances. The contribution to science is that the strengthening of pancasila values should always be done in any situation and condition, including in pandemic circumstances.

\section{CONCLUSION}

On the value of humanity, every human being must be recognized and treated according to his dignity and dignity as a Creature of God YME. Therefore, every community is entitled to fair protection and assistance from the government or other communities during this pandemic. The value of unity is the most fundamental in this pandemic, how each element of society can unite and work together to deal with the Covid-19 pandemic and its effects. People who can appreciate the provisions of the political elite or government to deal with Covid-19 are one of how to implement or how to apply the value of consultative and representative in this pandemic. Giving each other help without discriminating status to the community is an example of the application of social justice values in the pandemic. The government and the community must be able to synergize to help people who are especially affected by this pandemic by assisting their survival. The covid-19 pandemic does not know when it will end. However, it is expected that every community can carry out the values of Pancasila thoroughly by always paying attention to health protocols. Uniting together to be able to assist the affected communities is the duty of all of us. Respecting the government's decision is 
2416 Strengthening Pancasila Values During the Covid-19 Pandemic - Jagad Aditya Dewantara, T Heru Nurgiansah

DOI: https://doi.org/10.31004/edukatif.v3i4.443

one of our endeavors not to add to the positive case of this virus. and most importantly, always pray that this pandemic ends soon and we can do our usual activities.

\section{DAFTAR PUSTAKA}

Anwar, S., \& Salim, A. (2019). Pendidikan Islam Dalam Membangun Karakter Bangsa Di Era Milenial. AlTadzkiyyah: Jurnal Pendidikan Islam, 9(2), 233. Https://Doi.Org/10.24042/Atjpi.V9i2.3628

Asmaroini, A. P. (2016). Implementasi Nilai-Nilai Pancasila Bagi Siswa Di Era Globalisasi. Citizenship : Jurnal Pancasila Dan Kewarganegaraan, 4(2), 440-450. Https://Doi.Org/10.25273/Citizenship.V4i2.1077

Bunyamin, M. (2008). Internalisasi Nilai-Nilai Pancasila Dan Nasionalisme Melalui Pendidikan Kewarganegaraan. EDUCATIONIST, II(2), 134-144.

Cahyono, H., Suhono, S., \& Khumairo, A. (2018). Pendidikan Karakter Bagi Pelaku Pedofilia (Sebuah Strategi Dalam Mengatasi Amoral). JMKSP (Jurnal Manajemen, Kepemimpinan, Dan Supervisi Pendidikan), 3(1), 1-19. Https://Doi.Org/10.31851/Jmksp.V3i1.1519

Dewantara, J. A., \& Nurgiansah, T. H. (2021a). Building Tolerance Attitudes Of PPKN Students Through Multicultural Education Courses. Jurnal Etika Demokrasi, 6(1), 103-115.

Dewantara, J. A., \& Nurgiansah, T. H. (2021b). Efektivitas Pembelajaran Daring Di Masa Covid-19 Bagi Mahasiswa Universitas PGRI Yogyakarta. Jurnal Basicedu: Research \& Learning In Elementary Education, 5(1), 367-375.

Dewantara, J. A., Nurgiansah, T. H., \& Rachman, F. (2021). Mengatasi Pelanggaran Hak Asasi Manusia Dengan Model Sekolah Ramah HAM (SR-HAM). Edukatif: Jurnal Ilmu Pendidikan, 3(2), 261-269.

Hastangka, \& Farid, M. (2020). Kebijakan Politik Presiden Jokowi Terhadap Masalah Kewarganegaraan Dalam Merespons Isu Global: Studi Kasus Covid-19. Citizenship: Jurnal Pancasila Dan Kewarganegaraan, 8(1), 1-13.

Januar Mahardhani, A. (2020). Menjadi Warga Negara Yang Baik Pada Masa Pandemi Covid-19: Persprektif Kenormalan Baru. Jurnal Pancasila Dan Kewarganegaraan, 5(2), 65-76. Https://Doi.Org/10.24269/Jpk.V5.N2.2020.Pp65-76

Kahin. (2013). Nasionalisme Dan Revolusi Indonesia. Komunitas Bambu.

Krisnawati, D., Mey, E., \& Trisiana, A. (2020). Ketahanan Negara Republik Indonesia Masa Pandemik Covid-19. Jurnal Global Citizen Jurnal Ilmiah, 9(1), 51-62.

Kurniawan, M. I. (2015). Tri Pusat Pendidikan Sebagai Sarana Pendidikan Karakter Anak Sekolah Dasar. PEDAGOGIA: Jurnal Pendidikan, 4(1), 41-49. Https://Doi.Org/10.21070/Pedagogia.V4i1.71

Nafisah, D. (2016). Peran Pendidikan Muatan Lokal Terhadap Pembangunan Karakter Bangsa. Citizenship Jurnal Pancasila Dan Kewarganegaraan, 4(2), 451. Https://Doi.Org/10.25273/Citizenship.V4i2.1078

Novitasari, D., Ladamay, I., \& Wadu, L. B. (2019). Upaya Pembentukan Karakter Religius Islam Pada Siswa Melalui Keteladanan Di Sekolah Menengah Kejuruan. Prosiding Seminar Nasional, 3, 174-181.

Nurgiansah, T. H. (2020a). Build An Attitude Of Nationalism Students At SDN 7 Kadipaten With The Method Of Discusion In The Subject Ppkn. Jurnal Serunai Pendidikan Pancasila Dan Kewarganegaraan STKIP Budi Daya Binjai, 9(1), 1-11.

Nurgiansah, T. H. (2020b). Filsafat Pendidikan. In Banyumas: CV Pena Persada.

Nurgiansah, T. H. (2021a). Pendidikan Pancasila. In Solok: CV Mitra Cendekia Media.

Nurgiansah, T. H. (2021b). Pendidikan Pancasila Sebagai Upaya Membentuk Karakter Jujur. Jurnal Pendidikan Kewarganegaraan Undiksha, 9(1), 33-41.

Nurgiansah, T. H., Dewantara, J. A., \& Rachman, F. (2020). The Implementation Of Character Education In 
2417 Strengthening Pancasila Values During the Covid-19 Pandemic - Jagad Aditya Dewantara, T Heru Nurgiansah

DOI: https://doi.org/10.31004/edukatif.v3i4.443

The Civics Education Syllabus At SMA Negeri 1 Sleman. Jurnal Etika Demokrasi, 5(2), 110-121.

Nurgiansah, T. H., \& Sukmawati. (2020). Tantangan Guru Pendidikan Kewarganegaraan Di Masa Adaptasi Kebiasaan Baru. Jurpis: Jurnal Pendidikan Ilmu Sosial, 17(2), 139-149.

Octavia, E., \& Rube'i, M. A. (2017). Penguatan Pendidikan Karakter Berbasis Pancasila Untuk Membentuk Mahasiswa Prodi PPKN Menjadi Warga Negara Yang Baik Dan Cerdas. Jurnal Pendidikan Sosial, 4(1), 111-124. Http://Journal.Ikippgriptk.Ac.Id/Index.Php/Sosial/Article/View/427

Siahaan, M. (2020). Dampak Pandemi Covid-19 Terhadap Dunia Pendidikan. Jurnal Kajian Ilmiah, l(Juli), 1-3. Https://Doi.Org/10.31599/Jki.V1i1.265 